\title{
Isaac Israels: uit een schetsboek van een ziekenhuisopname uit 1919
}

\author{
C. van Weel
}

Isaac Israels (1865-1934) heeft zichzelf menigmaal geschilderd en getekend, portretten die ook in diverse musea voor het publiek te bezichtigen zijn. Dit 'zelfportret met verpleegster' is echter pas recent voor het eerst in de openbaarheid gekomen. Het toont de op dat moment 53-jarige schilder in een stoel met rechts achter zich een verpleegster. De huiselijke ambiance kan niet verhullen dat Isaac zich hier schilderde tijdens een opname, begin 1919, in het Zuidwalziekenhuis in Den Haag. Een schetsboek dat van deze opname resteert, staat eind 2006 begin 2007 centraal in twee exposities. Daar kan de bezoeker kennisnemen van de sfeer op de ziekenkamer: een tafeltje met een kleedje en daarop een vaas met bloemen; het uitzicht op de bomen op het binnenplein; een wagentje waarop medicijnen staan uitgestald. En vooral figureren veel verpleegsters - zoals de zuster achter de stoel - die tijdens hun werkzaamheden bereid werden gevonden om te poseren. Getuige het schetsboek namen zij een boek mee, speelden schaak met de patiënt of verrichtten verstelwerkzaamheden aan het ziekbed dit laatste was blijkbaar vlak na de eerste wereldoorlog een normaal onderdeel van de verpleegkundige dagtaak. Het werpt een apart licht op de in 1919 nog ruim beschik- bare, maar vandaag de dag node gemiste 'handen aan het ziekbed'.

Op 31 december 1918 werd Israels aan zijn voeten geopereerd, en vervolgens gedurende zes weken aan het ziekbed gekluisterd, was hij gedwongen om zijn inspiratie te ontlenen aan wie en wat zich op zijn ziekenkamer aandiende. Naast de reeds genoemde objecten behoorde daar ook zijn geschonden lichaam bij: de geopereerde voeten, die in verband gewikkeld of in pantoffels gestoken omhoog steken in zijn blikveld. De reconvalescentie stelde zijn geduld ernstig op de proef en dat lijkt tastbaar in dit zelfportret. De dikke zwarte strepen geven iets bedrukts aan de doorgaans toch lichtvoetig schilderende Israels. Ook zijn koffertje dat in enkele andere tekeningen in de hoek van de kamer is binnengeslopen, onderstreept zijn hunkering naar het 'normale' leven. Niet snel genoeg kon hij de draad van zijn reizende, kosmopolitische bestaan weer opvatten. Dat gebeurde ook, maar niet dan nadat hij een schetsboek had gevuld met prachtige tekeningen en aquarellen.

Voor een éénmalige expositie zijn alle bladen uit het boek gehaald zodat het publiek zich een beeld kan vormen van het verblijf van een van de meest vermaarde

C. van Weel $(\bowtie)$

Prof. dr. C. van Weel is hoogleraar huisartsgeneeskunde in het UMC St. Radboud, Nijmegen. Isaac Israels was de broer van zijn overgrootmoeder, Mathilde Cohen Tervaert- Israels. Naast deze familierelatie en het familiebezit van zijn werken is hij geboeid door het beeld van zieken, ziekte en medische zorg in kunst. 


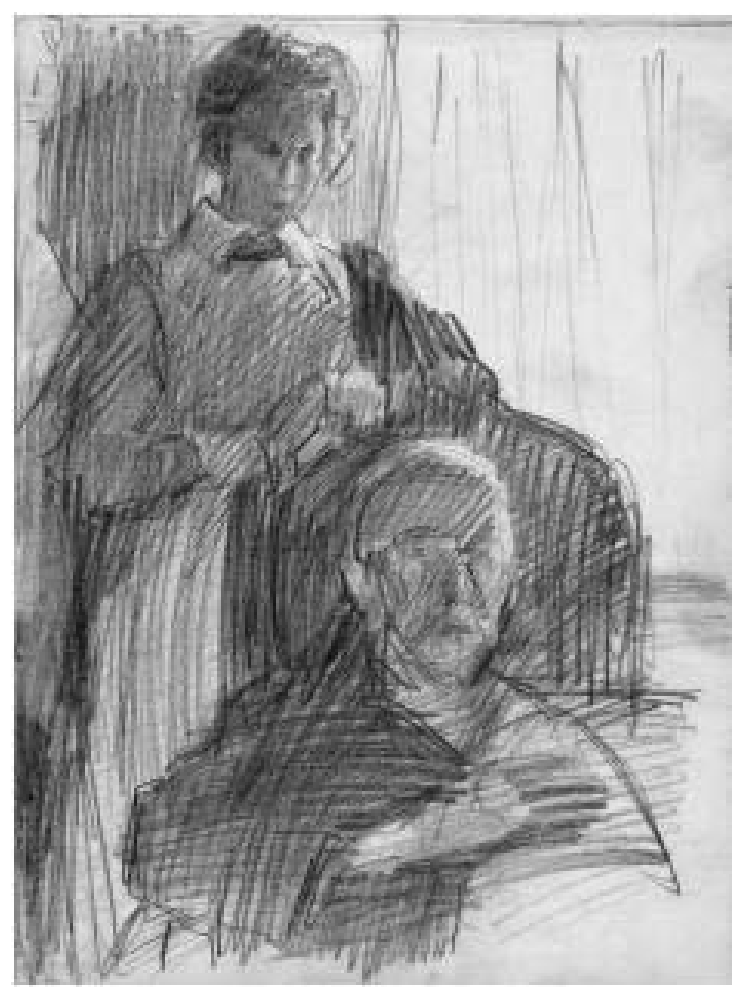

Zelfportret met verpleegster (Isaac Israels)

Nederlandse schilders van het einde van de $19 \mathrm{e}-$ begin 20e eeuw in het ziekenhuis - met tekeningen en aquarellen die stuk voor stuk een lust voor het oog zijn.

De tentoonstelling was tot eind januari 2007 te zien in Museum Het Valkhof in Nijmegen. Van 23 februari tot half mei 2007 is deze te zien in het Museum Mesdag in Den Haag. 